\title{
Understanding Religious Traveling from Central Asia to Saudi Arabia Using Cluster Analysis
}

\author{
Liza Rybina \\ Department of Management and Marketing, KIMEP University, Kazakhstan \\ Correspondence Author: Liza Rybina, Department of Management and Marketing, KIMEP University, Kazakhstan
}

Received date: 23 October 2018, Accepted date: 15 November 2018, Online date: 25 December 2018

Copyright: (C) 2018 Liza Rybina et al. This is an open-access article distributed under the terms of the Creative Commons Attribution License, which permits unrestricted use, distribution, and reproduction in any medium, provided the original author and source are credited.

\begin{abstract}
After getting independence from the 70-year-long enforced secularization process, the Central Asian countries have been anticipating an Islam revival that triggered religious tourism domestically and internationally. Central Asia has been disconnected from the Muslim heartland over the period under the Soviet regime. However, with the Islamic renaissance taking place in the region, the religious pilgrimage to Saudi Arabia is becoming a common trend among Muslim population. The cultural, social, and political significance of religious travel by Muslims is of vital importance. The focus of the current study is religious travel, including Hajj and Umrah. The main aim is to understand travel motivations of Muslim pilgrims from Central Asia to the Kingdom of Saudi Arabia. As motivations to visits sacred spaces can include a mixed range of both pilgrimage and secular motives, the present study examines relationship between religious and secular motives with travel intention and satisfaction of Muslim tourists. Moreover, the cluster analysis is applied to differentiate religious tourists from Central Asia based on their motivations to travel to Saudi Arabia. The analysis of the survey data of 285 pilgrims from Kazakhstan, Kyrgyzstan, Tajikistan, and Uzbekistan shows that while religious motives are related to both intention to visit and satisfaction, secular motives are related to intention, but not related to satisfaction of the Muslim tourists. The cluster analysis produced three groups of tourists: religious-motivated, hybrid-motived, and less-motivated. The recommendations are provided regarding how to approach and serve these three clusters of religious tourists in post-secular societies.
\end{abstract}

Key words: Pilgrimage, Islamic tourism, Religious motives, Secular motives, Cluster analysis

\section{INTRODUCTION}

Islamic revival in Central Asia: The Central Asian countries, especially after the collapse of Soviet regime, are seeing a revival in their religion which could be a boon for religious tourism [1]. The importance of the whole Asia in religious tourism is supported by the fact that of an estimated 600 million religious and spiritual voyages [2], around a half is in Asia. With limited research on religious travel and pilgrimage in post-Soviet countries, the main aim of the current study is to understand travel motivations of Muslim pilgrims from Central Asia to Saudi Arabia.

The cultural, social, and political significance of religious travel by Muslims is of vital importance. Performing the Hajj at least once in the lifetime is the fifth pillar of Islam and a duty on Muslims who can afford to do that financially and physically. The Hajj along with the Umrah and the lesser pilgrimage, such as Ziyarat (visiting sacred sites), constitutes an act of religious tourism that is unparalleled in other religions [3]. The Pew Research Center on Religion and Public Life in a comprehensive demographic study of more than 230 countries and territories [4] estimated that there were 5.8 billion religiously affiliated people around the globe, representing $84 \%$ of 6.9 billion world population. With more than eight-in-ten people identifying with a religious group, there were 2.2 billion Christians (32\%), 1.6 billion Muslims (23\%), 1 billion Hindus (15\%), nearly 500 million Buddhists (7\%) and 14 million Jews ( $0.2 \%$ of the world's population) as of 2010. Christianity has been by far the world's largest religion, however with the world's total population projected to increase to 9.3 billion between 2010 and 2050 (35\% increase), Muslims expected to rise by $73 \%$ over that same period. As a result, according to the Future of World Religions projections [5] of Pew Research Center, by 2050 there will be parity between Muslims (2.8 billion, or $30 \%$ of the population) and Christians (2.9 billion, or $31 \%$ ). Muslim population is projected to grow in absolute number in all regions of the world. Islam has emerged in Asia. It explains the fact that more than two-thirds of the World Muslim population resides in this continent [6]. Looking to the future, the Asia-Pacific region will remain to be the home of a majority of the Muslims in the world [5]. However, the population trends of Muslims living in different Asian countries vary. Countries with large current Muslim populations (such as Indonesia, Pakistan and Bangladesh) will anticipate a decline of Muslim population between 2010 and 2050, while other countries will demonstrate growth [5].

The Central Asian countries, after getting independence from the 70-year-long enforced secularization process, have been anticipating an Islam revival. This region consists of five countries: Kazakhstan, Kyrgyzstan, Tajikistan, Turkmenistan, and Uzbekistan. The total population of this region increased from 17.5 million in 1950 to 61.3 million in 2010 and projected to be 85.2 million by 2050 . The related percentage of Muslims in this region increased from $67 \%$ in 1950 to $89 \%$ in 2010 [6]. The corresponding individual data for each country in this region is summarized in Table 1. Tajikistan and Uzbekistan and have largest current Muslim populations (98.6\% and $96.3 \%$ ) followed by Turkmenistan (93\%) and Kyrgyzstan (91\%), while Kazakhstan has the lowest share of Muslims (70.8\%). Kazakhs unlike neighboring Uzbeks, did not have established social networks that would reproduce Islamic identity and the conversion of nomads of the Kazakh steppe to Islam at the early stages in the 12th-16th centuries was carried out by Sufi missionaries such as Nakhbandiya, Yassawiya, and Kadiriya [7, 8]. Having strong position of atheism inherited from Soviet times, when Islam virtually disappeared as an organizing religious doctrine and survived as rituals or as "folk Islam" [9], Kazakhstan may be constituted as possessing a low start in terms of religiosity in comparison with other Central Asian countries. 
Citation: Liza Rybina, 2018. Understanding Religious Traveling from Central Asia to Saudi Arabia Using Cluster Analysis. Journal of Applied Sciences Research., 14(6): 5-10. DOI: 10.22587/jasr.2018.14.6.2

Table 1: Muslim Population Trends in Central Asia 1950 - 2050 (in millions)

\begin{tabular}{|c|c|c|c|c|c|c|c|c|c|c|c|}
\hline & 1950 & 1960 & 1970 & 1980 & 1990 & 2000 & 2010 & 2020 & 2030 & 2040 & 2050 \\
\hline \multicolumn{12}{|l|}{ Uzbekistan } \\
\hline Population & 6.314 & 8.559 & 11.973 & 15.952 & 20.515 & 24.776 & 27.794 & 31.080 & 33.790 & 35.300 & 36.110 \\
\hline Muslims & 5.316 & 6.947 & 9.920 & 13.650 & 18.164 & 23.859 & 26.766 & 30.180 & 32.900 & 34.500 & 35.300 \\
\hline Muslims \% & 84.20 & 81.17 & 82.85 & 85.57 & 88.54 & 96.30 & 96.30 & 97.10 & 97.37 & 97.73 & 97.76 \\
\hline \multicolumn{12}{|l|}{ Kazakhstan } \\
\hline Population & 6.703 & 9.996 & 13.110 & 14.919 & 16.530 & 14.957 & 15.753 & 17.880 & 19.240 & 20.500 & 21.680 \\
\hline Muslims & 2.891 & 3.733 & 5.096 & 6.403 & 7.807 & 9.206 & 11.161 & 12.870 & 14.190 & 15.510 & 16.770 \\
\hline Muslims \% & 43.13 & 37.34 & 38.87 & 42.92 & 47.23 & 61.55 & 70.85 & 71.98 & 73.75 & 75.66 & 77.35 \\
\hline \multicolumn{12}{|l|}{ Tajikistan } \\
\hline Population & 1.532 & 2.082 & 2.942 & 3.953 & 5.303 & 6.173 & 7.075 & 8.430 & 9.910 & 11.170 & 12.280 \\
\hline Muslims & 1.356 & 1.702 & 2.469 & 3.404 & 4.759 & 6.088 & 6.978 & 8.130 & 9.540 & 10.750 & 11.800 \\
\hline Muslims \% & 88.51 & 81.72 & 83.95 & 86.11 & 89.74 & 98.63 & 98.63 & 96.44 & 96.27 & 96.24 & 96.09 \\
\hline \multicolumn{12}{|l|}{ Kyrgyzstan } \\
\hline Population & 1.740 & 2.173 & 2.964 & 3.627 & 4.395 & 4.955 & 5.550 & 6.190 & 6.940 & 7.630 & 8.220 \\
\hline Muslims & 1.181 & 1.288 & 1.837 & 2.414 & 3.170 & 4.217 & 5.049 & 5.540 & 6.280 & 6.980 & 7.600 \\
\hline Muslims \% & 67.86 & 59.28 & 61.97 & 66.56 & 72.13 & 85.10 & 90.97 & 89.50 & 90.49 & 91.48 & 92.46 \\
\hline \multicolumn{12}{|l|}{ Turkmenistan } \\
\hline Population & 1.211 & 1.594 & 2.188 & 2.861 & 3.668 & 4.502 & 5.177 & 5.740 & 6.300 & 6.680 & 6.910 \\
\hline Muslims & 0.930 & 1.250 & 1.783 & 2.402 & 3.249 & 4.191 & 4.819 & 5.340 & 5.850 & 6.210 & 6.420 \\
\hline Muslims \% & 76.81 & 78.44 & 81.45 & 83.97 & 88.58 & 93.09 & 93.09 & 93.03 & 92.86 & 92.96 & 92.91 \\
\hline \multicolumn{12}{|c|}{ Total Central Asia } \\
\hline Population & 17.499 & 24.403 & 33.177 & 41.312 & 50.411 & 55.362 & 61.349 & 69.320 & 76.180 & 81.280 & 85.200 \\
\hline Muslims & 11.674 & 14.919 & 21.105 & 28.274 & 37.149 & 47.560 & 54.773 & 62.060 & 68.760 & 73.950 & 77.890 \\
\hline Muslims \% & 66.71 & 61.14 & 63.61 & 68.44 & 73.69 & 85.91 & 89.2 & 89.53 & 90.26 & 90.98 & 91.42 \\
\hline
\end{tabular}

Sources: [5, 6]

In comparison with other heavily Islamic regions, religious orthodoxy in Islamic tradition in Central Asia remained low and determined by "the prevalence of the moderate Hanafi tradition across the region and the long history of secularization. The less-strict nature of the Hanafi madhab is more tolerant of diversities of belief and practice, and Hanafi societies have proven more accepting of secularization compared with other madhabs" [10, $p$ 79]. The non-Orthodox character of local Islam in Central Asia can be explained by the fact that throughout the history, Central Asian countries and in particular, Kazakhstan proved to be flexible to incorporate pre-Islamic traditions and local folk customs [10,11] and legitimized some tribal and customary law [8]. The Post-Soviet Central Asia has inherited a set of circumstances for the revitalization of religion [12,13] and flourishing of religious market $[14,15]$. Since the early post-Soviet period the public Islamic religious observance and commitment in Central Asia have increased notably signified by the widespread support for laws based in part on Islamic principles, including sharia [16], visibly seen in the sharp rise in the number of mosques, in mosque attendance, and pilgrimage travel [12]. Due to the Islamic renaissance taking place in the region, the religious pilgrimage to Saudi Arabia is becoming common trend among Muslim population.

Growth of Islamic Tourism and Pilgrimage: Pilgrimage is a tradition for almost all major religions worldwide. Despite the secular nature of modern societies, pilgrimage travel continues on an upward growth trajectory [17]. Islamic tourism can be traced to the early days of the Islamic civilization. It is rooted in the Islamic Sharia, where it is incumbent on every Muslim to visit the holy city of Mecca to conduct Hajj if he/she possesses the means and the ability to do so [18 ]. Therefore, any Muslim that does not live in the holy city has a duty to undertake tourism activities to fulfill Sharia requirements. Besides, millions of Muslims travel to Mecca every year to perform Umrah and visit sacred sites domestically and internationally to conduct Ziyarat (non-Hajj religiously motivated journeys, ziarat literally means a visit) [17, 19]. The number of Hajj pilgrims has fluctuated over the past decade (see figure 1).

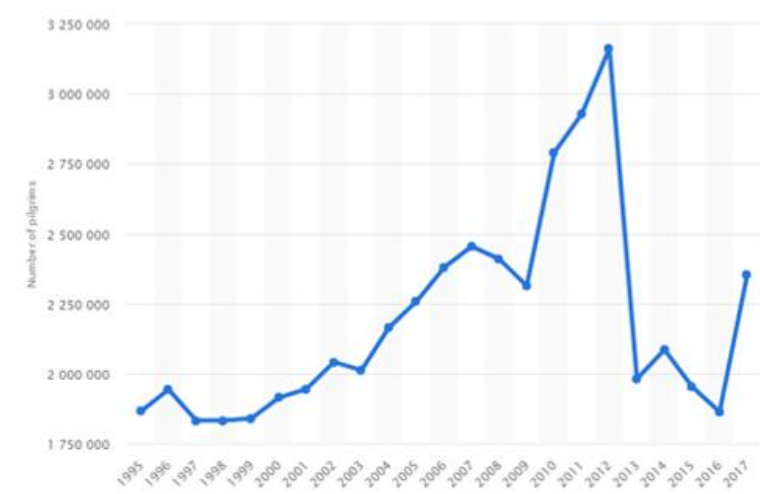

Fig1: Annual number of Hajj pilgrims to Saudi Arabia from 1995 to 2017.

Source: [20]

While 2.35 million worshippers, including 1.75 million from outside Saudi Arabia, performed the Hajj in 2017, the government expects to accommodate more worshippers with a target of receiving 3.75 million Hajj pilgrims by 2020, and 6.7 million by 2030 [21]. Muslims are encouraged to travel for historical, cultural, and social encounters, to gain knowledge, to associate with others, to enjoy and appreciate God's creations, and to spread God's word [22].

Several definitions of Islamic tourism can be found in literature $[1,23,24]$. In general, Islamic tourism is defined as tourism undertaken by Muslims or "any activity, event, experience or indulgence undertaken in a state of travel that is compliant with Islam, to interface within an Islamic framework with one or all of the following: history, culture, arts, heritage, way of life, economy, health, education and any other human interests" [ 25, p.37]. Islamic tourism can be divided into two categories: pilgrimage tourism activities or what is called Hajj and a new "touristic" interpretation of pilgrimage that merges religious and leisure tourism [18].

The focus of the current study is religious travel, including Hajj and Umrah, performed by pilgrims from Central Asia to the Kingdom of Saudi Arabia. The Hajj is conducted within a specific geographical territory (Almasha'er Almoukadasa) and conducted only at a particular time of the year. Hajj is performed "as a means of worship, recharging their spiritual serenity, revering their ancestor sacrifices, remembering the day hereafter and seeking forgiveness of sins" [ 17, $\mathrm{p}$. 236]. Umrah (a visit to Ka'abah) can be undertaken at any time of the year where pilgrims undertake similar rituals to those Muslims perform during Hajj, however they are not required to do them all. Islamic scholars highlight the relationship between following Islam's guidelines and Muslims' spirituality [17, 26]. Although it is a duty for a Muslim to travel to Mecca to fulfill Sharia requirements, "to increase their piety, seek forgiveness of sins, and perform supplications for the purpose 

Research., 14(6): 5-10. DOI: $10.22587 /$ jasr.2018.14.6.2

of fulfilling vows and/or seeking Allah's support' [17, p. 236], it is important to study travel motivations as a set of desires that influence participation in travel [27].

Past research showed that religious tourism experience was "a multi-faceted construct, which consists of engaging mentally, discovering new things, interacting and belonging, connecting spiritually and emotionally, and relaxing and finding peace dimensions" [28, p. 285]. Even when the prime motivation for pilgrimage is expressed as religious, motivations can include a mix of cultural, historical, social, aesthetic, and other non-religious factors. As the main aim of the current study is to understand travel motivations of pilgrims from Central Asia to Saudi Arabia, the following section will overview past studies on travel motivation.

\section{MOTIVATION FOR RELIGIOUS TRAVEL}

Motivation is a major determinant of the travelers' behavior [29]. The essential concept of motivation is a 'need' [30]. As a psychological concept, motivation is usually refers to an inner state or force which stimulates a person to perform certain practices in order to satisfy his or her internal sociopsychological needs and to respond to external factors [31]. Applied to tourism, travel motivations can be defined as a set of desires that influence individuals' participation in travel as a response [27]. Several theories were applied to explain travel motivations. One of the early and commonly accepted content theory developed by Abraham Maslow focuses on a need as the basis of motivation. In the hierarchy of needs theory, Maslow [32] asserted that people's needs can be divided into five different levels in a hierarchy of needs ranging from lower to higher order. Later, Pearce [33] proposed the Travel Career Ladder (TCL), a multi-motive model built on the Maslow Hierarchy of Needs, with five different levels of needs - physiological, safety or security, relationship, self-esteem or development, and fulfillment to understand travelers' motivations. The most popular Dann's [34] push-pull theoretical framework with specific reference to the question, "What makes tourists travel?" is concentrated on "push" factors, and, in particular, on those stemming from "anomie" and "ego-enhancement" in the tourist. Pull factors refer to destination's attributes that attract travelers while push factors are internal drives and desires of the travelers in undertaking a travelling activity [34, 35]. Crompton [36] suggested two cultural motives (novelty and education) and seven socio-psychological motives (escape from a perceived mundane, facilitation of social interaction, relaxation, exploration and evaluation of self, enhancement of kinship relationships and facilitation of social interaction, prestige, and regression) to explain tourist motivations. Motivation was defined by Iso-Ahola as "an internal factor that arouses, directs and integrates a person's behavior, implying a clear motivation-behavior relationship" (37, p. 130). Iso-Ahola's escaping/seeking theory states that tourists' behavior is influenced simultaneously by two motivational forces, illustrated in a four quadrant model incorporating personal escape, personal seeking, interpersonal escape, and interpersonal seeking.

With a vast number of studies on travel motivation, there is a steam of research into motivations for religious and spiritual tourism. The research on religious motivation to travel was first initiated by Eliade [38] who indicated that religions have sacred centers that people desire to visit. Early studies often distinguished between pilgrims and tourists. Some suggested that pilgrims visit sacred spaces to gain "emotional release" from the world of everyday and temporary release from social ties [39]. Timothy and Olsen [22] suggest that people are motivated to travel to sacrosanct sites searching for truth, enlightenment, or an authentic experience with the divine. In conceptualization of pilgrimage, spiritual tourism, personal heritage tourism, holistic tourism, and valuistic journeys, the recent study of Liutikas [40] concludes that valuistic travelers have very clear motivation to travel and during the journey they perform different religious or secular rituals. Pilgrimage is often situated within the constraints of established religions and prompted by the devotional aspects prescribed by traditional religions and their motives for pilgrimages [41]. In modern tourism, it is difficult to distinguish a pilgrim from the tourism. Smith proposed infinite sacred-secular combinations between two extremes of the continuum with pilgrims at one end and tourists at the other [42]. The typology developed by Santos [43] locates tourism and religion at opposite ends of a continuum, with the combinations between the two based on the religious background, the values travelers place on specific religious spaces, and the experiences they expect to have. The recent conceptual framework for spiritual tourism [44] questions the demarcation between secular and religious drivers and proposes a continuum of spiritual tourism motivations with two drivers at distinct ends with an additional acknowledgement of hybrid motivations predicated on both religious and secular foundations.

In the motivational research in tourism, the constructs of motives are often related to tourists' willingness or intention to visit, destination loyalty, and satisfaction of tourists $[45,46]$. Maximizing travel satisfaction is crucial for a successful tourism destination management. As motivations to visits sacred spaces can include a mixed range of both pilgrimage and secular motives, the following hypotheses were stated for this study in the context of religious travel from central Asia to Saudi Arabia:

H1a: Religious motives are related to travel intention of religious tourists from Central Asia to Saudi Arabia

H1b: Religious motives are related to satisfaction of religious tourists from Central Asia to Saudi Arabia

H2a: Secular motives are related to travel intention of religious tourists from Central Asia to Saudi Arabia

H2b: Secular motives are related to satisfaction of religious tourists from Central Asia to Saudi Arabia

H3: Religious tourists from Central Asia vary in their motivations to travel to Saudi Arabia

\section{MATERIALS AND METHODS}

Description of the Study Area: A survey of religious travelers from central Asia to Saudi Arabia was conducted using a questionnaire. The target sample respondents were from four countries with represented number of pilgrims visiting Mecca (Uzbekistan (7200), Kyrgyzstan (5400), Tajikistan (5400) and Kazakhstan with 2777 pilgrims of 3000 quota for 2018). There were no respondents surveyed from Turkmenistan as the state limits the number of religious visitors to Saudi Arabia to around 180 per year despite the quota of 3000 (there were only 153 religious tourists to Saudi Arabia in 2018) [47, 48].

Data Collection: A combination of convenience and snowballing sampling was used for data collection because of limited access to Central Asian religious tourists in Saudi Arabia. Both paper and online contact methods were applied to collect quantitative survey data. The study uses the attitudinal approach based on self-reported data collection technique. The construct measures were derived from the scales for religious and secular motives used in the past studies [17, 28, 45, $49,50,51]$. The religious motives included the following items: "Expressing love and respect for God", "Searching for forgiveness", "Getting closer to something sacred", "Seeking out opportunities to help me grow spiritually ", "Fulfilling one of the Five Pillars of Islam", "Visiting the center of the Muslim world". The secular motives included the following items: "Authentic experiences help me understand the cultural heritage of my people", "I like to expand my knowledge when I visit a sacred site", "I am interested in history of the sacred sites", "Following the modern trends in traveling", "Witnessing the beauty and harmony of nature". The Intention to visit construct was measured by two items: 'I would like to visit Mecca in the future' and 'I would recommend my friends and relatives to visit Mecca'. Tourist satisfaction was measured by two items: "In general, how satisfied were you with your visit to Saudi Arabia?" and "How would you evaluate Saudi Arabia compared to your expectations?". The scales were measured on a five point Likert type scale with 1 "not important at all" to 5 "very important" for motivation and 1 "absolutely disagree" to 5 "absolutely agree" for intention. The questionnaire contained basic demographic questions. The factor analysis, analysis of variance (MANOVA) and cluster analysis were conducted to test hypotheses.

\section{RESULTS AND DISCUSSION}

The final sample consisting of 285 respondents was used for data analysis. The sample demographics are presented in table 2 . The age varied from 20 to 75 years old. There were $74.9 \%$ of males and $25.1 \%$ of females. About two thirds of respondents have visited Saudi Arabia at least once. One out of ten persons travelled to Mecca more than five times.' The Principal Component Factor Analysis with varimax rotation was conducted on the items comprising scales (see the table 3). Items produced low loadings or loaded on two factors were eliminated from further research. The final scale consisted of 4 items for religious motives and 3 items for secular motives. The Kaiser-Meyer-Olkin Test for Sampling Adequacy produced a KMO of 0.69, which is higher than 0.6 threshold level meaning that the sample can be used for analysis. The reliability scores ( 0.75 and 0.79$)$ meet the guidelines for Cronbach's alpha [52]. The resulting factors were used further for the analysis of variance and cluster analysis. 
Citation: Liza Rybina, 2018. Understanding Religious Traveling from Central Asia to Saudi Arabia Using Cluster Analysis. Journal of Applied Sciences Research., 14(6): 5-10. DOI: 10.22587/jasr.2018.14.6.2

Table 2: Sample Characteristics

\begin{tabular}{|l|l|l|l|}
\hline Characteristics & Categories & Frequency (N) & Percentage (\%) \\
\hline & $20-30$ & 33 & 11.6 \\
Age & $31-40$ & 60 & 21.1 \\
(years) & $41-50$ & 92 & 32.3 \\
& $51-60$ & 63 & 22.1 \\
\hline Gender & Over 60 & 25 & 13.0 \\
\hline \multirow{5}{*}{ Monthly Personal Income } & Male & 213 & 74.9 \\
(in USA Dollars) & Female & 72 & 25.1 \\
& Less than $\$ 300$ & 49 & 19.4 \\
& $\$ 300-500$ & 50 & 19.8 \\
& $\$ 501-1000$ & 66 & 26.2 \\
& $\$ 1001-3000$ & 64 & 25.4 \\
Education & Above \$3000 & 16 & 6.3 \\
& Did not respond & 7 & 2.8 \\
\hline \multirow{5}{*}{ Past Visits to Saudi Arabia } & High School & 66 & 26.2 \\
& Undergraduate/Diploma & 119 & 47.2 \\
& Graduate & 56 & 22.2 \\
& Doctoral & 9 & 3.6 \\
& Did not respond & 2 & 0.8 \\
\hline
\end{tabular}

Table 3: Factor Analysis Loadings

\begin{tabular}{|l|l|}
\hline Constructs / Items & Item loadings \\
\hline Religious Motives & \\
\hline Fulfilling one of the Five Pillars of Islam & 0.750 \\
\hline Seeking out opportunities to help me grow spiritually & 0.766 \\
\hline Expressing love and respect for God & 0.708 \\
\hline Searching for forgiveness & 0.585 \\
\hline Secular Motives & \\
\hline Authentic experiences help me understand the cultural heritage of my people & 0.794 \\
\hline I like to expand my knowledge when I visit a sacred site & 0.791 \\
\hline I am interested in history of the sacred site & 0.729 \\
\hline Satisfaction & \\
\hline In general, how satisfied were you with your visit to Saudi Arabia? & 0.685 \\
\hline How would you evaluate Saudi Arabia compared to your expectations? & 0.680 \\
\hline Intention to visit & \\
\hline I would like to visit Saudi Arabia in the future & 0.820 \\
\hline I would recommend my friends and relatives to visit Saudi Arabia & 0.868 \\
\hline
\end{tabular}

To examine the relationship between Religious and Secular motives with Intention to visit and Satisfaction, multivariate analysis (MANOVA) with Religious and Secular motives fixed and Intention to visit and Satisfaction as dependent variables was performed. The model produced adjusted R square of 0.563 . The results show that both Religious and Secular motives have significant positive relationship with Intention to visit (p-values are 0.00 and 0.01 ), while only Religious motivation is significantly related to Satisfaction (p-value is 0.00 ). Secular motivation was not proven to be significantly related to Satisfaction (p-value is 0.97). Thus, Hypotheses $1 \mathrm{a}$ and $1 \mathrm{~b}$ that stated that religious motives are related to travel intention and satisfaction of religious tourists from Central Asia to Saudi Arabia are supported. Hypothesis 2a that states that secular motives are related to travel intention of religious tourists from Central Asia to Saudi Arabia is supported but Hypothesis $2 \mathrm{~b}$ stating that secular motives are related to satisfaction of religious tourists from Central Asia to Saudi Arabia is not supported. The findings of the present study are consisted with the past research that state that even the most committed pilgrims and religious travelers have leisure needs [17].

Although the main motivation for pilgrimage is religious, travelers usually have a mix of both pilgrimage and secular motives. Islam in Central Asia is quite non-orthodox due to the pre-Islamic traditions and a 70-year long Soviet atheism period. This has implications for the pilgrimage tourism. In order to improve tourist satisfaction with travel experiences, destination managers must address the religious motivations. Both religious and secular motivations and their positive relationship to intention to visit should be considered to attract tourists and build destination loyalty.

The travel agencies, tour operators, hotels, and other providers of services in both Central Asia and Saudi Arabia can benefit from deeper understanding of tourism behavior and motivation of travelers from secular societies such as Central Asian states.

As segmented approaches could bring more satisfaction to travelers and gains for tourism providers, cluster analysis, recommended by previous research [53], was further applied to test Hypothesis 3 stating that religious tourists from Central Asia vary in their motivations to travel to Saudi Arabia and to identify specific groupings of respondents. Two-Step Cluster Analysis was performed on the entire sample with the number of clusters limited to the maximum five clusters. The analysis produced 3 clusters distributed as follow - $112(39.2 \%), 105(36.8 \%)$, and $68(23.8 \%)$ of the total sample. The ration of the largest to smallest cluster is 1.64 which is better than a recommended maximum threshold of 3 . The description of the resulting clusters is presented in the Table 4 below.

Table 4: Cluster Analysis Results

\begin{tabular}{|l|l|l|l|}
\hline $\begin{array}{l}\text { Cluster } \\
\text { Characteristics }\end{array}$ & $\begin{array}{l}\text { Cluster 1 } \\
\text { Religious motivated }\end{array}$ & $\begin{array}{l}\text { Cluster 2 } \\
\text { Hybrid motivated }\end{array}$ & $\begin{array}{l}\text { Cluster 3 } \\
\text { Less motivated }\end{array}$ \\
\hline Size & $112(39.2 \%)$ & $105(36.8 \%)$ & $68(23.8 \%)$ \\
\hline Religious motivation & 4.42 & 4.14 & 3.43 \\
\hline Secular motivation & 2.38 & 3.88 & 2.70 \\
\hline Intention to visit & 4.47 & 4.46 & 2.79 \\
\hline Age (Min/Max/Mean), years & $20 / 75 / 40.8$ & $23 / 70 / 44.4$ & $20 / 65 / 36.8$ \\
\hline Gender, \% male & 75.7 & 76.9 & 70.6 \\
Gender, \% female & 24.3 & 23.1 & 29.4 \\
\hline
\end{tabular}

The first cluster's size is 105 (36.8\%). Respondents who belong to this cluster are mostly males (75.7\%), age varies from 20 to 75 with mean of 40.8 . They have the highest among three clusters score for religious motivation (4.42) and intention to visit Saudi Arabia (4.47) and lowest score for secular motives (2.38). Based on the characteristics of this cluster it was named "Religious motivated travelers". The second cluster's size is 112 (39.2\%). This cluster has the highest 
Citation: Liza Rybina, 2018. Understanding Religious Traveling from Central Asia to Saudi Arabia Using Cluster Analysis. Journal of Applied Sciences Research., 14(6): 5-10. DOI: 10.22587/jasr.2018.14.6.2

number of males (76.9\%), age varies from 23 to 70 with mean of 44.4. This group has the highest, out of three clusters, score for secular motivation (3.88) and almost as high as the first cluster intention to visit Saudi Arabia (4.46). The score for religious motives is in between two other clusters (4.14). Despite the fact that this cluster has the highest score for secular motives (3.88), it is lower that the score of this cluster for religious motivation (4.14). Based on the characteristics of this cluster, it was named "Hybrid motivated travelers". The third cluster's size is 68 (23.8\%). This cluster has the highest composition of females (29.4\%) compared to other groups, age varies from 20 to 65 with mean of 36.8 years old. This group has the lowest, out of three clusters, score for religious motivation (3.43) and an average in contrast with other clusters score for secular motives (2.7). The representatives from this cluster are the least interested in visiting Saudi Arabia (2.79). Based on the characteristics of this cluster, it was named "Less motivated travelers". Partially, the findings of this study fit the previous typologies of tourists $[42,43,44]$. Smith proposed infinite sacred-secular combinations between two extremes of the continuum with pilgrims at one end and tourists at the other [42]. The typology developed by Santos [43] describes combinations of tourism and religion based on the religious background. The recent conceptual framework for spiritual tourism proposed by Cheer, Belhassen and Kujawa [44] sets a continuum of spiritual tourism motivations with secular drivers focused on self and religious drivers focused on institution along with hybrid motivations in the overlapping area. The results of this study fit, widely discussed now, postsecular tourism approach, stating that "post-secular tourism (re)construct pilgrimage places in novel ways, neither sacral nor secular, but rather a hybrid or combination of both [54, p. 172].

\section{CONCLUSIONS}

The focus and the aim of the current study were religious tourism and understanding travel motivations of Muslim pilgrims from Central Asia to the Kingdom of Saudi Arabia. According to "the secularization thesis, religion was supposed to wane or disappear and give way for science and rational thought" [54, p. 161]. Nevertheless, Central Asian states demonstrate the return to religious traditions. The analysis of the survey data of 285 pilgrims from Kazakhstan, Kyrgyzstan, Tajikistan, and Uzbekistan showed that while religious motives are related to both intention to visit and satisfaction, secular motives are related to intention, but not related to satisfaction of the religious tourists. These findings have implications for the success of pilgrimage destinations. In order to improve satisfaction with travel experiences, destination managers must consider the religious motivations. Also, managers of religious destinations should consider the role of secular motivations and their positive relationship to intention to visit and destination loyalty. The appropriate destination activities should be delivered to tourists in order to enhance destination competitiveness.

The cluster analysis revealed three groups of tourists: religious-motivated, hybrid-motived, and less-motivated. The implications of having three different clusters of religious tourists is that segmented approach and positioning strategies can be taken to serve these distinct groups. The results show the importance of both religious and secular attribute values on Muslim tourists' willingness to travel to Islamic destination. Based on these findings, pilgrimage and religious organizations are advised to periodically investigate pilgrim traveler motivations as well as their needs and wants to tailor service provision to their desired experiences.

In light of the religious diversity that characterizes modern post-Soviet societies, future research can explore pilgrimage tourism in diverse religious realms. Moreover, a study of post-secular religiosity and tourism can shed more light on understanding travel motivations of modern pilgrims.

\section{REFERENCES}

[1] Henderson, J. 2009. Islamic tourism reviewed. Tourism Recreation Research, 34(2): 207-211.

[2] Lanquar, R. G. 2011. Pilgrims between East and West. In Religious Tourism in Asia and the Pacific. World Tourism Organization. Madrid, Spain, 1-6.

[3] Scott, N. and J. Jafari. 2011. Islam and Tourism. In Religious Tourism in Asia and the Pacific. World Tourism Organization. Madrid, Spain, 47-56.

[4] Pew Research Center. 2012. The Global Religious Landscape. Pew Research Center on Religion and Public Life. Retrieved on August 24, 2018 from http://www.pewforum.org/2012/12/18/global-religious-landscape-exec/

[5] Pew Research Center. 2015. The Future of World Religions: Population Growth Projections, 2010-2050. Pew Research Center on Religion and Public Life. Retrieved on August 24, 2018 from http://www.pewforum.org/2015/04/02/religious-projections-2010-2050/

[6] Kettani, H. 2010. Muslim Population in Asia: 1950 - 2020. International Journal of Environmental Science and Development, 1(2): 143-153.

[7] Salmorbekova, Z. and G. Yemelianova, 2009. Islam and Islamism in the Ferghana Valley. In Radical Islam in the Former Soviet Union, Eds. G. Yemelianova, London and New York: Routledge, 213-214.

[8] Kassenova, N. 2018. Kazakhstan: Islamic Revival and Trajectories of State-Society Relations. In Religion, Conflict, and Stability in the Former Soviet Union. Eds., Migacheva, K and B. Frederick. RAND Corporation, Santa Monica, Calif. 115-136

[9] Sultangaliyeva, A. 2012. Return of Islam' to Kazakhstan [Vozrasheniye islama' v Kazakhstane], Almaty, Kazakhstan: Foundation of Altynbek Sarsenbayev, p: 23.

[10] Cornell, S. E. 2018. Central Asia: Where Did Islamic Radicalization Go? In Religion, Conflict, and Stability in the Former Soviet Union. Eds., Migacheva, K and B. Frederick. RAND Corporation, Santa Monica, Calif. 65-96.

[11] Tasar, E. 2016. The Official Madrasas of Soviet Uzbekistan. Journal of the Economic and Social History of the Orient, 59: 265-302.

[12] Radford, D. 2014. Contesting and negotiating religion and ethnic identity in Post-Soviet Kyrgyzstan. Central Asian Survey, $33(1): 15-28$.

[13] Haberstroh. M. 2011. The Silk Roads of Faith. In Religious Tourism in Asia and the Pacific. World Tourism Organization. Madrid, Spain, 11-14

[14] McBrien, J. 2006. Extreme Conversations: Secularism, Religious Pluralism, and the Rhetoric of Islamic Extremism in Southern Kyrgystan. In The Postsocialist Religious Question: Faith and Power in Central Asia and East Central Europe, Eds., Hann, C. LIT Verlag, Berlin, 47-73.

[15] Pelkmans, M. 2006. Asymmetries on the Religious Market. In The Postsocialist Religious Question: Faith and Power in Central Asia and East Central Europe, Eds., Hann, C. LIT Verlag, Berlin, $29-46$.

[16] Collins, K. 2007. Islamic Revivalism and Political Attitudes in Uzbekistan. National Council for Eurasian and East European Research, 36-39.

[17] Almuhrzi, H. M. \& A. M. Alsawafi, 2017. Muslim perspectives on spiritual and religious travel beyond Hajj: Toward understanding motivations for Umrah travel in Oman. Tourism Management Perspectives, 24: 235-242.

[18] Eid, R. and E.G. Hatem. 2015. Muslim Tourist Perceived Value in the Hospitality and Tourism Industry. Journal of Travel Research, 54(6): 774-787

[19] Jafari, J., and N. Scott. 2014. Muslim World and Its Tourisms. Annals of Tourism Research. 44: 1-19.

[20] Statista. 2018. Number of Hajj pilgrims in Saudi Arabia 1995-2017. Travel, Tourism \& Hospitality. Retrieved on August 24, 2018 from https://www.statista.com/statistics/617696/saudi-arabia-total-hajj-pilgrims/

[21] Oxford Business Group. 2018. Visitor Numbers On The Up. Saudi Arabia Economy Overview. Retrieved on August 24,2018 from https://oxfordbusinessgroup.com/overview/grand-plans-sustained-focus-raising-pilgrim-numbers-and-expanding-beyond-religion-oriented-tourism

[22] Timothy D. J. and D. H. Olsen. 2006. Tourism and religious journeys. In Tourism, Religion and Spiritual Journeys. Eds. Timothy D. J. and Olsen D. H. London and New York: Routledge, 1-21.

[23] Eid, R. 2015. Integrating Muslim customer perceived value, satisfaction, loyalty and retention in the tourism industry: an empirical study. International Journal of Tourism Research, 17(3): 249-260.

[24] Jafari, A. 2012. Islamic marketing: insights from a critical perspective. Journal of Islamic Marketing, 3(1): 22-34.

[25] Nassar, M. A., M. M. Mostafa and Y.Reisinger. 2015. Factors influencing travel to Islamic destinations: an empirical analysis of Kuwaiti nationals. International Journal of Culture, Tourism and Hospitality Reseacg, 9(1): 36-53.

[26] Ibrahim, I. 2007. A brief illustrated guide to understanding Islam. Houston: Dar Ussalam.

[27] Schofield, P., \& K. Thompson, 2007. Visitor motivation, satisfaction and behavioral intention: The 2005 Naadam festival, Ulaanbaatar. International Journal of Tourism Research, 9, 329-344.

[28] Albayraka, T., R. Hersteinb, M. Cabera, N. Drorib, M. Bidecia and R. Bergerb, 2018. Exploring religious tourist experiences in Jerusalem: The intersection of Abrahamic religions. Tourism Management, 69: 285-296. 
[29] Wong, B. K. M., G. Musa and A. Z. Taha, 2017. Malaysia my second home: The influence of push and pull motivations on satisfaction. Tourism Management, 61: 394-410.

[30] Mansfeld, Y. and A. Pizam, 1999. Consumer behavior in travel and tourism. New York: An Imprint of The Haworth Press.

[31] Jang, S., B. Bai, C. Hu and C. Wu, 2009. Affect, travel motivation, and travel intention: A senior market. Journal of Hospitality and Tourism Research, 33(1): 51-73.

[32] Maslow, A. H. 1954. Motivation and personality. New York: Harper and Row.

[33] Pearce, P. L. 1993. Fundamentals of Tourist Motivation. In Tourism Research: Critiques and challenges. Eds. Pearce, D and R. Butler. London: Routledge, $113-134$.

[34] Dann, G. 1977. Anomie, ego-enhancement and tourism. Annals of Tourism Research, 4(4): 184-194.

[35] Dann, G. 1981. Tourism motivations; an appraisal. Annals of Tourism Research, 8(2): 189-219.

[36] Crompton, J. L. 1979. Motivations for Pleasure Vacations. Annals of Tourism Research, 6: 408 -424.

[37] Iso-Ahola, E. 1982. Towards a social psychology theory of tourism motivation: A rejoinder. Annals of Tourism Research, 9 (2): $256-262$.

[38] Eliade, M. 1961. The Sacred and the Profane: The Nature of Religion, New York: Harper \& Row.

[39] Eade, J. 1992. Pilgrimage and tourism at Lourdes, France. Annals of Tourism Research, 19: 18-32.

[40] Liutikas, D. 2017. The manifestation of values and identity in travelling: The social engagement of pilgrimage. Tourism Management Perspectives, 24: 217224.

[41] Kujawa, J. 2017. Spiritual tourism as a quest. Tourism Management Perspectives, 24: 193-200.

[42] Smith, V.L. 1992. Introduction: the quest in guest. Annals of Tourism Research, 19: 1-17.

[43] Santos M.D.G.M.P. 2003. Religious tourism: Contributions towards a clarification of concepts. In Religious Tourism and Pilgrimage: ATLAS Special Interest Group, 1st Expert Meeting. Eds. Fernandes C., F. McGettigan and J. Edwards. Fátima, Portugal: Tourism Board of Leiria/Fátima, 27-42.

[44] Cheer, J. M., Y. Belhassen and J. Kujawa. 2017. The search for spirituality in tourism: Toward a conceptual framework for spiritual tourism. Tourism Management Perspectives, 24: 252-256.

[45] Yoon, Y. and M. Uysal. 2005. An examination of the effects of motivation and satisfaction on destination loyalty: a structural model. Tourism Management, 26: $45-56$.

[46] Wong, M. and R. Cheung. 2013. A Study on Traveler Expectation, Motivation and Attitude. Contemporary Management Research, 9(2): 169-186.

[47] General Authority for Statistics Kingdom of Saudi Arabia. 2018. Hajj Statistics. Retrieved on August 242018 from www.stats.gov.sa

[48] Sputnik News. 2018. Retrieved on August 242018 from https://ru.sputniknews.kz/society/20180718/6471496/haj-2018-pravila.html

[49] Amaro, S., A. Antunes and C. Henriques. 2018. A closer look at Santiago de Compostela's pilgrims through the lens of motivations. Tourism Management 64: $271-280$.

[50] Ambrosio, V. 2015. Sacred pilgrimage and tourism as secular pilgrimage. In Religious tourism and pilgrimage management: An international perspective (2nd ed.). Eds. Raj, R. and K. Griffin Wallingford, UK: CABI. 130-145.

[51] Bozic, S., B. Spasojevic, M. D. Vujicic and I. Stamenkovic. 2016. Exploring The Motives Of Religious Travel By Applying The Ahp Method - The Case Study Of Monastery Vujan (Serbia). International Journal of Religious Tourism and Pilgrimage, 4(4): 33-47. Available at: https://arrow.dit.ie/ijrtp/vol4/iss $4 / 4$

[52] Hair, J.F., W.C. Black, B.J. Babin, R.E. Anderson and R.L. Tatham. 2006. Multivariate Data Analysis. Vol. 6, Pearson Prentice Hall, Upper Saddle River.

[53] Mo, C. M., D. R. Howard and M. E. Havitz. 1993. Testing an international tourist role typology. Annals of Tourism Research, 20(2): 310-335.

[54] Nilsson, M and M. Tesfahuney. 2018. The post-secular tourist: Re-thinking pilgrimage tourism. Tourist Studies, 18(2): $159-176$. 